\title{
Effects of rumen-undegradable protein on intake, performance, and mammary gland development in prepubertal and pubertal dairy heifers
}

\author{
A. L. Silva, ${ }^{*}$ E. Detmann, ${ }^{*}$ J. Dijkstra,† A. M. Pedroso,‡ L. H. P. Silva, ${ }^{*}$ A. F. Machado, ${ }^{*}$ F. C. Sousa, $\S$ \\ G. B. dos Santos,\# and M. I. Marcondes*1 \\ *Department of Animal Science, Universidade Federal de Viçosa, 36570-000 Viçosa, Minas Gerais, Brazil \\ †Animal Nutrition Group, Wageningen University, 6700 AH Wageningen, the Netherlands \\ $\ddagger$ Cargill Animal Nutrition, 13091-611 Campinas, São Paulo, Brazil \\ §Department of Agricultural Engineering, Universidade Federal de Viçosa, 36570-000 Viçosa, Minas Gerais, Brazil \\ \#Faculty of Veterinary, Universidade Federal Fluminense, 24220-900 Niterói, Rio de Janeiro, Brazil
}

\begin{abstract}
The objective of this study was to evaluate the influence of different amounts of rumen-undegradable protein (RUP) on intake, $\mathrm{N}$ balance, performance, mammary gland development, carcass traits, and hormonal status of Holstein heifers at different physiological stages (PS). Sixteen prepubertal (PRE) heifers (initial $\mathrm{BW}=106 \pm 7.6 \mathrm{~kg}$; age $=4.3 \pm 0.46 \mathrm{mo})$ and 16 pubertal (PUB) heifers (initial $\mathrm{BW}=224 \pm 7.9$ $\mathrm{kg}$; age $=12.6 \pm 0.45 \mathrm{mo}$ ) were used in an experiment over a period of $84 \mathrm{~d}$. Four diets with increasing RUP contents $(38,44,51$, and $57 \%$ of dietary crude protein) and heifers at 2 PS (PRE or PUB) were used in a $4 \times$ 2 factorial arrangement of treatments in a completely randomized design. Throughout the experiment, 2 digestibility trials were performed over 5 consecutive days (starting at d 36 and 78) involving feed and ort sampling and spot collections of feces and urine. At $d$ 0 and 83, body ultrasound images were obtained for real-time carcass trait evaluation. The mammary gland was ultrasonically scanned at d 0 and every 3 wk during the experiment. Blood samples were taken at $d 0$ and 84 to determine serum concentrations of progesterone, estrogen, insulin-like growth factor I (IGF-I), and insulin. No interaction between PS and the level of RUP was found for any trait. Apparent digestibility of dry matter, organic matter, and neutral detergent fiber corrected for ash and protein was not affected by RUP level but was lower for PRE compared with PUB heifers. Sorting against neutral detergent fiber corrected for ash and protein (tendency only) and for crude protein was greater for PUB than PRE heifers. Pubertal heifers had greater average daily gain (905 vs. $505 \mathrm{~g} / \mathrm{d}$ ) and $\mathrm{N}$ retention (25.9 vs. $12.5 \mathrm{~g} / \mathrm{d}$ ) than PRE heifers.
\end{abstract}

Received May 24, 2017.

Accepted February 23, 2018.

${ }^{1}$ Corresponding author: marcos.marcondes@ufv.br
In addition, average daily gain and $\mathrm{N}$ retention were greatest at $51 \%$ RUP of dietary protein. Mammary ultrasonography indicated no effects of RUP amounts on mammary gland composition, whereas PRE heifers had greater pixel values than PUB, indicating higher contents of fat rather than protein in the mammary glands of PRE heifers. Serum progesterone and IGF-I concentration was affected only by PS, and PRE heifers had greater values of progesterone and IGF-I concentrations than PUB heifers. Serum insulin concentration was unaffected by PS but tended to be higher at $51 \%$ of RUP. In conclusion, an RUP level of $51 \%$ increases body weight, average daily gain, feed efficiency, and $\mathrm{N}$ retention in heifers regardless of the PS. In addition, PRE heifers have a lower sorting ability and reduced intake, total-tract digestibility, and $\mathrm{N}$ retention. They also have higher amounts of fat in their mammary glands, even at moderate growth rates.

Key words: growth, mammary gland ultrasound, nitrogen retention

\section{INTRODUCTION}

The rearing of heifers is a key issue on dairy farms because these animals represent the herd's maintenance and renovation. However, the replacement of cows by heifers accounts for a large proportion of milk production costs, and practices that allow heifers to grow faster from birth to the first calving can increase profits by reducing the effects of heifers on farm costs (Sejrsen and Purup, 1997; Geiger et al., 2016). As reproductive characteristics are correlated with $\mathrm{BW}$, high growth rates have been used as a strategy to reduce age at first calving (NRC, 2001; Piantoni et al., 2012; Albino et al., 2015).

One way to improve the ADG of growing heifers is to increase the RUP content in the diet, providing more MP (Tomlinson et al., 1997). However, studies of the RUP use in dairy heifers' diets are still scarce, and the 
results are not conclusive. For instance, cattle fed with fish or blood meals showed improved performance and $\mathrm{N}$ retention (Bethard et al., 1997; Zanton et al., 2007); in contrast, feeding corn gluten meal had no positive effect on performance (Santos et al., 1998; Ribeiro et al., 2005). To the best of our knowledge, no studies have used rumen-protected soybean meal as an RUP source in heifer diets, although soybean meal has been widely used as feedstuff for cattle and is easy to treat to improve RUP contents.

Besides improving the ADG, there is another persistent concern about a potential negative effect of growth rate on the mammary gland development of dairy heifers in which a high growth rate at key periods has been linked to the deposition of fat instead of epithelial secretory tissue (Geiger et al., 2016). Diets with additional dietary protein, which increases MP provision, may prevent excessive body fat deposition (Bascom et al., 2007) and may induce greater parenchymal tissue deposition than fat pad accumulation on the mammary gland of growing dairy heifers. In this sense, Capuco et al. (2004) demonstrated that the provision of additional dietary protein (from 14.9 to $16.9 \%$ ), supplied as RUP, was associated with increasing growth rates of dairy heifers without negative effects on mammary gland development or milk production at first lactation. Additionally, Albino et al. (2015) demonstrated that diets with high MP/ME ratio induced greater parenchymal tissue deposition in Holstein heifers. Therefore, as RUP supply is able to increase MP flow (Mezzomo et al., 2011; Batista et al., 2106, 2017), it could be expected that increases in dietary RUP could also affect mammary gland development.

Most studies have proposed that mammary gland development is more pronounced during the prepubertal phase (Whitlock et al., 2002; Daniels et al., 2009; Piantoni et al., 2012), and for this reason, this phase is more sensitive to changes in the mammary gland composition (Sinha and Tucker, 1969). However, inadequate feed management (e.g., excessive ADG or low $\mathrm{MP} / \mathrm{ME}$ ratio) may negatively affect mammary gland development, even during the pubertal phase (Sejrsen et al., 1986; Purup et al., 2000; Rowson et al., 2012).

Furthermore, despite the large number of studies about dairy heifer performance and mammary gland development, to the best of our knowledge, the study of Sejrsen et al. (1982) was the only work to evaluate mammary gland development in prepubertal (PRE) and pubertal (PUB) heifers simultaneously. Therefore, we hypothesized that increasing amounts of RUP from soybean meal would increase the available MP and improve intake, performance, and mammary gland development; we further hypothesized that the response would be different for PRE and PUB Holstein dairy heifers. We evaluated the influence of increasing dietary RUP amounts from soybean meal on intake, performance, $\mathrm{N}$ balance, carcass traits, mammary gland development, and hormonal status of Holstein dairy heifers before and after puberty.

\section{MATERIALS AND METHODS}

All animal handling and procedures described in the present study were approved by the Ethics Commission on the Use of Farm Animals of the Universidade Federal de Viçosa (Viçosa, MG, Brazil) under protocol no. $039 / 2015$.

\section{Animals, Experimental Design, and Feeding}

Thirty-two Holstein heifers were divided into 2 groups according to their physiological stage (PS): PRE heifers $(106 \pm 7.6 \mathrm{~kg}$ of BW, $4.3 \pm 0.46$ mo old, and serum progesterone concentration of $0.24 \pm 0.023 \mathrm{ng} / \mathrm{mL}$ ) and PUB heifers $(224 \pm 7.9 \mathrm{~kg}$ of BW, $12.6 \pm 0.45$ mo old, and serum progesterone concentration of $1.04 \pm 0.012$ $\mathrm{ng} / \mathrm{mL})$. Four diets with increasing RUP contents (38, 44,51 , and $57 \%$ of dietary protein) and heifers at $2 \mathrm{PS}$ stages (PRE or PUB) were used in a $4 \times 2$ factorial arrangement of treatments in a completely randomized design. Thus, 8 treatments, with 4 replicates each, were established: $38,44,51$, and $57 \%$ of RUP for PRE heifers and $38,44,51$, and $57 \%$ of RUP for PUB heifers.

The heifers were individually housed in stalls with an area of $10 \mathrm{~m}^{2}$ and provided with feed bunks and drinkers. A fresh TMR of the respective diet (Table 1; Supplemental Table S1, https://doi.org/10.3168/jds .2017-13230) was delivered twice per day at 0700 and $1500 \mathrm{~h}$, providing ad libitum access to feed. Diets were formulated to meet nutrient requirements according to the NRC (2001) guidelines for Holstein heifers with 1.0 $\mathrm{kg} / \mathrm{d}$ of ADG. The experiment lasted for a period of $84 \mathrm{~d}$, which was preceded by a 15-d pre-experimental period to adapt the animals to the diets, facilities, and management. Heifers were weighed in the morning at $d$ 0 (immediately before beginning the experiment) and on the last day of the experiment after $16 \mathrm{~h}$ of fasting to obtain the shrunk BW.

\section{Total Apparent Digestibility Trial, Analyses, and Calculations}

Two digestibility trials were carried out from d 36 to 40 (first digestibility trial) and from d 78 to 82 (second digestibility trial), recording individual intake and sampling offered feeds, orts, feces, and urine. During the 5 consecutive days of the digestibility trial, 8 spot 
Table 1. Dietary ingredients and chemical composition of diets for dairy heifers fed different amounts of RUP (38, 44, 51 , and $57 \%$ of dietary protein) before (PRE) or after (PUB) puberty

\begin{tabular}{|c|c|c|c|c|c|c|c|c|}
\hline \multirow[b]{2}{*}{ Item } & \multicolumn{4}{|c|}{ PRE } & \multicolumn{4}{|c|}{ PUB } \\
\hline & 38 & 44 & 51 & 57 & 38 & 44 & 51 & 57 \\
\hline \multicolumn{9}{|l|}{ Diet composition, \% of DM } \\
\hline Corn silage & 70.0 & 70.0 & 70.0 & 70.0 & 70.0 & 70.0 & 70.0 & 70.0 \\
\hline Corn meal & 2.6 & 2.6 & 2.6 & 2.6 & 8.7 & 8.7 & 8.7 & 8.7 \\
\hline Soybean meal & 21.8 & 14.5 & 7.3 & - & 15.1 & 10.0 & 5.1 & - \\
\hline By-pass soybean meal & - & 7.3 & 14.5 & 21.8 & - & 5.1 & 10.0 & 15.1 \\
\hline Minerals & 2.0 & 2.0 & 2.0 & 2.0 & 1.2 & 1.2 & 1.2 & 1.2 \\
\hline \multicolumn{9}{|l|}{ Chemical composition } \\
\hline $\mathrm{OM}, \%$ of DM & 92.4 & 92.4 & 92.4 & 92.4 & 93.9 & 93.9 & 93.9 & 93.9 \\
\hline $\mathrm{CP}, \%$ of $\mathrm{DM}$ & 17.5 & 17.6 & 17.6 & 17.7 & 14.4 & 14.4 & 14.5 & 14.6 \\
\hline NDFap, ${ }^{1} \%$ of DM & 38.4 & 38.5 & 38.5 & 38.5 & 38.6 & 38.7 & 38.7 & 38.7 \\
\hline Gross energy, Mcal $/ \mathrm{kg}$ of DM & 4.13 & 4.14 & 4.14 & 4.15 & 4.06 & 4.06 & 4.06 & 4.07 \\
\hline $\mathrm{RUP} / \mathrm{CP},{ }^{2} \%$ of $\mathrm{CP}$ & 37.3 & 43.7 & 50.1 & 56.4 & 38.3 & 43.8 & 49.0 & 54.4 \\
\hline
\end{tabular}

${ }^{1} \mathrm{NDF}$ corrected for ash and protein.

${ }^{2}$ Amount of RUP in total CP (calculated using values obtained in the in situ trial).

collections of feces and urine were made every $15 \mathrm{~h}$, starting at $0600 \mathrm{~h}$ of the first day of each trial (d 36 and 78). At each collection point, approximately 200 $\mathrm{g}$ of feces was sampled by stimulating defecation. In addition, urine samples of approximately $50 \mathrm{~mL}$ were obtained by stimulated urination; the samples were immediately frozen to prevent $\mathrm{N}$ losses. At the end of each digestibility trial, samples of feeds, orts, and feces were pooled and stored at $-20^{\circ} \mathrm{C}$. To pool the urine samples, $10 \mathrm{~mL}$ of pure urine was diluted in $40 \mathrm{~mL}$ of sulfuric acid $(0.036 \mathrm{~N})$ and stored $\left(-20^{\circ} \mathrm{C}\right)$ to prevent purine derivate degradation (Valadares et al., 1999).

Samples of feeds, orts, and feces were oven $\operatorname{dried}\left(55^{\circ} \mathrm{C}\right)$ and ground to 2 and $1 \mathrm{~mm}$ using a knife mill (Detmann et al., 2012). The 1-mm samples were analyzed for DM (AOAC International, 2005; method 934.01), CP content (AOAC International, 2005; method 990.13), ash content (AOAC International, 2005; method 942.05), and NDF corrected for ash and protein contents [NDFap; Detmann et al., 2012; Instituto Nacional de Ciência e Tecnologia-Ciência Animal (INCT-CA), Brazil, methods F-002/1, N-004/1, and M-002/1], and gross energy was measured using a dynamic calorimeter (C 5001, IKA, Wilmington, NC). The 2-mm samples were used to determine indigestible NDF, which was used as an internal marker to estimate fecal DM excretion. Briefly, samples of feeds, orts, and feces were incubated in the rumen of a cow over a period of $240 \mathrm{~h}$ using nonwoven textile bags $\left(100 \mathrm{~g} / \mathrm{m}^{2}\right)$, and NDF was estimated in the postincubation material (Valente et al., 2011).

The composition of feeds and orts was used to estimate nutrient intake, whereas feces composition, together with intake, was used to estimate total apparent diet digestibility. The ME content was calculated using the factor 0.82 as the efficiency of use of digestible energy (NRC, 2001). In addition, the contents of NDFap and CP of the offered feed and orts were used to assess the sorting behavior of the animals, which was calculated as the relation between the actual intake and the predicted intake of each fraction (Leonardi and Armentano, 2003). Values equal to $100 \%$ indicate no sorting activity, whereas values under $100 \%$ indicate refusal (sorting against) and values greater than $100 \%$ indicate preferential intake (sorting for).

The urine samples were analyzed for $\mathrm{N}$ content (AOAC International, 2005; method 990.13), and creatinine was measured using the colorimetric endpoint method with the use of picrate and acidifier (Labtest Diagnóstica S. A. Lagoa Santa, Minas Gerais, Brazil). In addition, the concentrations of uric acid and allantoin in the urine were determined according to Fujihara et al. (1987) and Chen and Gomes (1992), respectively. Total daily urinary excretion was estimated using the daily creatinine excretion as proposed by Chizzotti et al. (2008) for Holstein cattle. Ruminal microbial CP (CPmic) synthesis was estimated as a function of absorbed purines, which was calculated from the excretion of the purine derivatives uric acid and allantoin, according to the equations proposed by Prates et al. (2012) for Holstein heifers.

The flow of MP from microorganisms was calculated as follows:

$$
\mathrm{MPmic}=\mathrm{CPmic} \times 0.64
$$

where MPmic $=$ MP from microorganisms $(\mathrm{g} / \mathrm{d})$; CPmic $=$ microbial $\mathrm{CP}(\mathrm{g} / \mathrm{d})$; and $0.64=$ conversion factor of CPmic to true digestible CPmic, which considers 
that the CPmic has $80 \%$ of true protein and $80 \%$ of digestibility (NRC, 2001).

\section{Mammary Gland Ultrasound}

The mammary gland was ultrasonically scanned at d 0 and every 3 wk throughout the experiment. Mammary gland ultrasound images were taken using a microconvex transducer (Mindray DP2200, Shenzhen, China), operating at a frequency of $6 \mathrm{MHz}$ (see Albino et al., 2017). Images were taken of each mammary quarter in a standardized position, with an inclination of $45^{\circ}$ in relation to teat insertion, and recorded in bitmap format, a technique described by Nishimura et al. (2011) and adapted by Albino et al. (2017).

Mammary gland ultrasound images were evaluated for pixel values in an 8-bit format as described by Albino et al. (2015) using the software ImageJ (National Institutes of Health, Bethesda, MD). The pixel value was determined according to the brightness in a scale of 256 shades of gray $(0=$ black and $256=$ white $)$. Prior to the analysis, the software was calibrated for a pixel scale of 100 pixels $/ \mathrm{cm}$ using the straight tracer tool.

The pixel value of each mammary quarter was obtained as the mean from 3 squares $\left(16 \mathrm{~mm}^{2}\right.$ each) randomly collected near the ductal structures from each image. Subsequently, the pixel value of the whole mammary gland was obtained as an average value of the mammary quarters. Structures made up mainly of fat tissue have a high ability to reflect sound waves and present greater pixel values, whereas parenchymal tissue has a limited ability to reflect sound waves and presents lower pixel values (Albino et al., 2015).

\section{Real-Time Carcass Trait Evaluation}

At d 0 and 83, heifers were ultrasonically scanned between the 12th and 13th ribs using an 18-cm linear array ultrasound instrument (Aloka SSD-500V, Aloka Co. Ltd., Tokyo, Japan) operating at a frequency of 3.5 MHz. A standoff and vegetable oil were used to guarantee adequate acoustic contact between the transducer and the standoff as well as between these and the animals' skin. Ultrasound images were recorded and later analyzed for back fat thickness (BFT) and ribeye area (REA) using the software BioSoft Toolbox II for Beef (Biotronics Inc., Ames, IA). The BFT is presented in millimeters, and REA is presented as square centimeters.

\section{Blood Sampling and Analysis}

Blood samples were taken at d 0 and 84 from the jugular vein into $10-\mathrm{mL}$ evacuated tubes containing separator gel and clot activator. The tubes were kept on ice until centrifugation $\left(3,000 \times g\right.$ at $4^{\circ} \mathrm{C}$ for $\left.20 \mathrm{~min}\right)$ to obtain blood serum. The serum was pipetted into Eppendorf tubes and stored $\left(-20^{\circ} \mathrm{C}\right)$ until analysis.

The serum concentrations of progesterone, estrogen, insulin, and IGF-I were evaluated via chemiluminescence immunoassay (Immulite 1000; Siemens Medical Solutions Diagnostics, Los Angeles, CA) with a sensitivity of $0.1 \mathrm{ng} / \mathrm{mL}, 20 \mathrm{pg} / \mathrm{mL}, 0.1 \mu \mathrm{IU} / \mathrm{mL}$, and 25 $\mathrm{ng} / \mathrm{mL}$ for progesterone, estrogen, insulin, and IGF-I, respectively.

\section{In Situ Degradability Trial}

Two rumen-cannulated Holstein heifers $(325 \pm 20.6$ $\mathrm{kg}$ ) were used to estimate RDP and RUP of feedstuffs via an in situ ruminal trial. The animals were individually housed and fed the $38 \%$ of RUP for PUB heifers diet twice per day. Nylon bags with an inner size of $15 \times 8 \mathrm{~cm}$ and a pore size of $50 \mu \mathrm{m}$ (Sefar Nitex, Thal, Switzerland) were filled with approximately 5 $\mathrm{g}$ of 2-mm ground samples of corn silage, corn meal, soybean meal, by-pass soybean meal, or wheat bran. Three bags were simultaneously incubated through the ruminal cannula in each animal for $16 \mathrm{~h}$ (Calsamiglia and Stern, 1995; Paz et al., 2014). After this time, the bags were removed from the rumen, washed under running water, and oven dried at $55^{\circ} \mathrm{C}$. The residuals were analyzed for DM and CP contents as described above. The RDP content (\% of DM) of the feed ingredients was estimated as the amount of $\mathrm{CP}$ (\% of DM) that disappeared from the nylon bag after incubation, and RUP (\% of DM) was estimated as CP - RDP. Subsequently, actual RUP intake was estimated via the multiplication of CP intake by the RUP content of each diet. To estimate the flow of MP from feedstuffs, the actual RUP intake was multiplied by RUP digestibility, which was estimated considering the RUP digestibility of each feed according to the NRC (2001) guidelines, and its proportion in each diet. In addition, total MP intake was estimated by the sum of MP from microorganisms and from feedstuffs.

\section{Statistical Analysis}

The data were analyzed using the MIXED procedure of SAS (SAS Institute Inc., 2008) and following the basic statistical model

$$
\mathrm{Y}_{\mathrm{ijk}}=\mu+\mathrm{RUP}_{\mathrm{i}}+\mathrm{PS}_{\mathrm{j}}+(\mathrm{RUP} \times \mathrm{PS})_{\mathrm{ij}}+\varepsilon_{\mathrm{ijk}},
$$

where $Y_{\mathrm{ijk}}=$ dependent variable, $\mu=$ overall mean, $\mathrm{RUP}_{\mathrm{i}}=$ fixed effect of dietary RUP amounts, $\mathrm{PS}_{\mathrm{j}}=$ fixed effect of physiological state, $(\mathrm{RUP} \times \mathrm{PS})_{\mathrm{ij}}=$ fixed 
effect of interaction between dietary RUP amounts and physiological stage, and $\varepsilon_{\mathrm{ijk}}=$ random error.

Data from the digestibility trials and pixel values from the mammary gland images, which were taken at different times, were included as repeated measures (time effect) in the experimental model

$$
\begin{aligned}
\mathrm{Y}_{\mathrm{ijklm}}= & \mu+\mathrm{RUP}_{\mathrm{i}}+\mathrm{PS}_{\mathrm{j}}+(\mathrm{RUP} \times \mathrm{PS})_{\mathrm{ij}}+\delta_{\mathrm{ijk}} \\
+ & \mathrm{T}_{1}+(\mathrm{RUP} \times \mathrm{T})_{\mathrm{il}}+(\mathrm{PS} \times \mathrm{T})_{\mathrm{j} l} \\
& +(\mathrm{RUP} \times \mathrm{PS} \times \mathrm{T})_{\mathrm{ijl}}+\varepsilon_{\mathrm{ijklm}},
\end{aligned}
$$

where $Y_{\mathrm{ijklm}}=$ dependent variable; $\mu=$ overall mean; RUP $_{i}=$ fixed effect of dietary RUP amounts; $P_{\mathrm{j}}=$ fixed effect of physiological stage; $(\mathrm{RUP} \times \mathrm{PS})_{\mathrm{ij}}=$ fixed effect of interaction between dietary RUP amounts and PS; $\delta_{\mathrm{ijk}}=$ random error where the variance between animals within treatments $(\mathrm{RUP}+\mathrm{PS}+\mathrm{RUP} \times \mathrm{PS})$ is equal to the covariance between repeated measurements within animals; $\mathrm{T}_{1}=$ fixed effect of sampling time; $(\mathrm{RUP} \times \mathrm{T})_{\mathrm{il}}=$ fixed effect of interaction between RUP and time; $(\mathrm{PS} \times \mathrm{T})_{\mathrm{jl}}=$ fixed effect of interaction between PS and time; $(\text { RUP } \times \text { PS } \times \mathrm{T})_{\mathrm{ijl}}=$ fixed effect of interaction among RUP amounts, PS, and time; and $\varepsilon_{\mathrm{ijklm}}=$ random error. The variance components, compound symmetry, heterogeneous compound symmetry, heterogeneous first-order autoregressive, and unstructured matrices of (co)variance were tested. The matrix selection was based on the corrected Akaike information criterion, and we selected the heterogeneous compound symmetry covariance structure.

The pixel values from the mammary gland images did not follow a normal distribution, and a logarithmic transformation was therefore applied. The initial measurements of carcass traits and serum hormone concentrations were used as covariables in the experimental model for each respective variable. Additionally, initial BW was included as a covariable for variables related to intake and performance in the experimental model. For all analyses, the DIFF option was included at the LSMEANS command to provide multiple comparisons; differences were declared when $P<0.05$, and a tendency was declared for $0.05 \leq P<0.10$.

\section{RESULTS}

Interaction effects between time of collection (digestibility trial or mammary gland ultrasonography) and either dietary RUP $(P=0.653)$ or PS $(P=0.543)$ or both $(P=0.764)$ were not observed for the variables tested in this study (data not shown). Likewise, interaction effects between dietary RUP amounts and PS were not observed for any of the variables (Tables 2, 3, 4, 5, and 6$)$.

\section{Intake, Digestibility, and Sorting Behavior}

Total daily intake was greater in the second digestibility trial compared with the first digestibility trial $(P$ $<0.05$; Table 2). In addition, total daily intake of DM, OM, CP, NDFap, and ME was not affected by dietary RUP $(P>0.05$; Table 2). However, RUP and RDP intakes were affected $(P<0.001$; Table 2$)$ by dietary RUP, and as aimed RUP intake increased and RDP intake decreased as dietary RUP increased.

An effect $(P<0.001)$ of PS was observed for total daily intake, and PRE heifers presented lower average values than PUB heifers (Table 2). In addition, relative DMI $(\mathrm{g} / \mathrm{kg}$ of $\mathrm{BW})$ was not affected by PS $(P=$ $0.637)$, dietary RUP $(P=0.268)$, or time of collection (digestibility trials; $P=0.131$; Table 2). However, ME intake relative to ingested $\mathrm{DM}$ content $(\mathrm{Mcal} / \mathrm{kg}$ of ingested DM) and ME intake relative to BW (Mcal/ $\mathrm{kg}$ of BW) were affected by PS, and PRE heifers had a lower content and relative intake than PUB heifers. Additionally, total and relative feed intake was evaluated throughout the experiment, and a similar pattern was observed (Supplemental Table S2, https://doi.org/ 10.3168/jds.2017-13230).

Total-tract apparent digestibility was not affected by time of collection (digestibility trials) or dietary RUP amounts $(P>0.05$; Table 3$)$. However, we observed an effect $(P=0.001)$ of PS on the apparent digestibility of DM, OM, and NDFap, and PRE heifers presented a lower digestibility than PUB heifers (Table 3), with an average DM digestibility of 67.2 and $70.8 \%$, respectively. In contrast, we found a greater $(P=0.005) \mathrm{CP}$ apparent digestibility for PRE heifers (Table 3).

Sorting behavior against NDFap tended to be affected $(P=0.095)$ by PS, and PRE heifers showed a tendency to have lower sorting activity than PUB heifers (Table 3). Likewise, PRE heifers also exhibited $(P=0.011)$ a lower selection capacity in favor of dietary $\mathrm{CP}$ than PUB heifers (Table 3).

\section{Performance and Carcass Traits}

Final shrunk BW $(P<0.001)$, feed efficiency $(P<$ $0.001)$, and ADG $(P=0.024)$ were affected by dietary RUP and were greater for $51 \%$ of RUP compared with other dietary RUP (Table 4). Animal performance was also affected $(P=0.001)$ by PS, and the ADG was $79 \%$ greater for PUB than for PRE heifers, with average values of 905 and $505 \mathrm{~g} / \mathrm{d}$, respectively. In addition, PRE heifers had better feed efficiency values than PUB heifers, with averages of 156 and $139 \mathrm{~g} / \mathrm{kg}$, respectively (Table 4).

Carcass traits were affected only $(P=0.001)$ by PS, and PUB heifers had greater values for both BFT and 


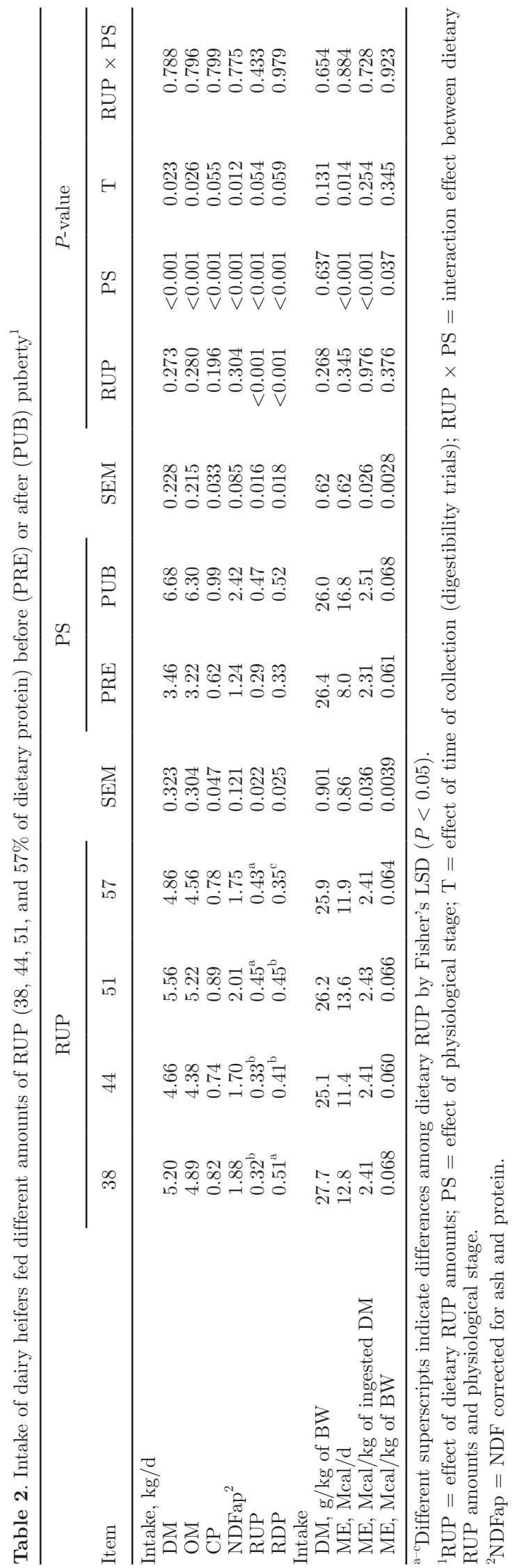

REA (Table 4). However, when carcass traits were analyzed relative to BW, no effects of dietary RUP amounts or PS were observed (Table 4).

\section{N Balance, Microbial Synthesis, and Protein Flow}

The $\mathrm{N}$ intake was not affected by dietary RUP ( $P$ $=0.196)$; however, regarding PS, PUB heifers had a greater $(P<0.001) \mathrm{N}$ intake than PRE heifers, averaging 158.8 and $98.4 \mathrm{~g} / \mathrm{d}$, respectively (Table 5). Urinary $\mathrm{N}$ excretion showed a tendency to be lower in treatments with high RUP $(P=0.081$; Table 5$)$. Fecal and urinary excretion of $\mathrm{N}$ were lower $(P<0.001)$ for PRE compared with PUB heifers. Retained $\mathrm{N}$ was greater $(P$ $<0.001$; Table 5) for PUB compared with PRE heifers, averaging 25.9 and $15.4 \mathrm{~g} / \mathrm{d}$, respectively. Additionally, retained $\mathrm{N}$ was affected by dietary RUP $(P=0.023$; Table 5), presenting greater values for treatments with $51 \%$ of RUP compared with other dietary RUP (Table $5)$.

The CPmic synthesis, efficiency of CPmic synthesis, and the efficiency of use of $\mathrm{N}$ for CPmic synthesis were affected $(P<0.05)$ by dietary RUP, and treatments with $57 \%$ of RUP had lower values compared with the other treatments (Table 5). In addition, CPmic synthesis and the efficiency of use of $\mathrm{N}$ for CPmic synthesis were affected by PS, and PRE heifers presented lower values than PUB heifers (Table 5). On the other hand, we observed a tendency effect $(P=0.086$; Table 5$)$ of PS on efficiency of CPmic synthesis, and PRE heifers exhibited greater efficiency of CPmic synthesis than PUB heifers.

The flow of digestible RUP was greater $(P<0.001)$ for PUB than PRE heifers, averaging 367 and $245 \mathrm{~g} / \mathrm{d}$, respectively. The average flow of digestible RUP was affected by dietary RUP $(P=0.001$; Table 5$)$, and greater values were observed for treatments with 51 and $57 \%$ of RUP compared with other treatments (Table 5). The MP flow was greater $(P<0.001)$ for PUB than PRE heifers, averaging 699 and $432 \mathrm{~g} / \mathrm{d}$, respectively. Additionally, MP flow was affected by dietary RUP $(P=$ 0.021 ), and greater values were observed for treatments with $51 \%$ of RUP (Table 5).

\section{Mammary Gland Development and Hormonal Status}

The analysis of pixel values from the mammary gland ultrasound images did not point out any effects of time of collection $(P=0.372)$ and dietary RUP amounts $(P=0.282$; Table 6$)$ on mammary gland development. However, an effect $(P=0.035)$ of PS was observed, and PRE heifers presented greater pixel values than PUB heifers. 
Table 3. Apparent digestibility and sorting activity of dairy heifers fed different amounts of RUP (38, 44, 51, and $57 \%$ of dietary protein) before (PRE) or after (PUB) puberty ${ }^{1}$

\begin{tabular}{|c|c|c|c|c|c|c|c|c|c|c|c|c|}
\hline Item $^{1}$ & \multicolumn{4}{|c|}{ RUP } & SEM & \multicolumn{2}{|c|}{ PS } & SEM & \multicolumn{4}{|c|}{$P$-value } \\
\hline $\mathrm{DM}$ & 68.7 & 69.1 & 69.1 & 69.1 & 0.839 & 67.2 & 70.8 & 0.593 & 0.979 & $<0.001$ & 0.305 & 0.743 \\
\hline $\mathrm{OM}$ & 70.5 & 71.2 & 71.0 & 71.1 & 0.753 & 69.4 & 72.5 & 0.532 & 0.927 & $<0.001$ & 0.595 & 0.677 \\
\hline $\mathrm{CP}$ & 73.0 & 72.3 & 72.4 & 71.5 & 0.804 & 73.5 & 71.1 & 0.568 & 0.567 & 0.005 & 0.287 & 0.966 \\
\hline $\mathrm{NDFap}^{2}$ & 58.9 & 61.2 & 59.6 & 60.7 & 0.972 & 58.2 & 61.9 & 0.687 & 0.368 & 0.001 & 0.763 & 0.798 \\
\hline $\mathrm{CP}$ & 119.5 & 116.4 & 130.1 & 120.5 & 0.069 & 113.6 & 129.7 & 0.048 & 0.426 & 0.011 & - & 0.961 \\
\hline
\end{tabular}

${ }^{1}$ RUP $=$ effect of dietary RUP amounts; PS $=$ effect of physiological stage; $\mathrm{T}=$ effect of time of collection (digestibility trials); RUP $\times$ PS $=$ interaction effect between dietary RUP amounts and physiological stage.

${ }^{2} \mathrm{NDFap}=\mathrm{NDF}$ corrected for ash and protein.

${ }^{3}$ Sorting values equal to $100 \%$ indicate no sorting, $<100 \%$ indicate selective refusals (sorting against), and $>100 \%$ indicate preferential consumption (sorting for).

Initial progesterone levels were $0.24 \pm 0.071$ and 1.03 $\pm 0.071 \mathrm{ng} / \mathrm{mL}$ for PRE and PUB heifers, respectively (data not shown). The final blood concentration of progesterone was not affected by dietary RUP amounts $(P$ $=0.775)$ and was greater for PUB compared with PRE heifers $(P=0.001)$, averaging $1.39 \pm 0.104$ and 0.58 $\pm 0.104 \mathrm{ng} / \mathrm{mL}$, respectively (Table 6). Blood estrogen concentration was not affected $(P>0.05)$ by dietary RUP amounts or by PS (Table 6). Serum IGF-I was affected $(P=0.001$; Table 6$)$ only by PS, and PUB heifers had greater concentrations than PRE heifers $(296.5 \pm 16.21$ vs. $148.4 \pm 16.21 \mathrm{ng} / \mathrm{mL})$. In addition, serum insulin levels were not affected $(P=0.550$; Table $6)$ by PS but presented a tendency $(P=0.077)$ to be greater in treatments with $51 \%$ of RUP.

\section{DISCUSSION}

The results of the initial and final progesterone measurements indicate that all animals kept their PS throughout the experiment because animals with progesterone levels equal to or greater than $1 \mathrm{ng} / \mathrm{mL}$ are considered pubertal (Cooke and Arthington, 2009). Hence, there were no changes in the PS of the heifers during the experiment, which could cause confounding effects.

As observed by Jiao et al. (2014) and confirmed by our study, young heifers have a lower capacity to digest NDFap, which can be linked to a lower ruminal microbial activity of these animals. As shown in Table 5, the use of consumed $\mathrm{N}$ for microbial synthesis was lower for PRE than for PUB heifers, which reveals a certain ruminal inefficiency of these animals. Therefore, with a lower microbial synthesis, fiber digestibility was diminished, which contributed to a lower DM digestibility in PRE than in PUB heifers.
The behavior of PUB heifers to select feeds against dietary NDFap and in favor of dietary CP indicates that this ability is intrinsically bound to their experience throughout their lives, preferences, and postingestive feedback in addition to an attempt to optimize the ingestion of nutrients and energy (Provenza and Balph, 1987). In contrast, PRE heifers are under a selection learning process because they are young; because they are still in the transition stage (between 2 and 3 mo old), they receive the forage and concentrate feeds separately. Therefore, they are not fit to consume the diet in TMR form, which would make the selection activity more difficult.

The feed selection inability of PRE heifers resulted in a tendency toward greater NDFap selection (Table 3), which, combined with a lower NDFap digestibility and consequently a lower DM digestiblity, resulted in a lower ME content of the ingested diet (\% of DM; Table 2). As the performance is directly affected by energy intake (Brown et al., 2005), the lower ME (Mcal/ $\mathrm{kg}$ of BW; Table 2) of PRE heifers resulted in lower ADG and $\mathrm{N}$ retention (Tables 4 and 5). Overall, the sorting behavior and digestibility results reveal the importance of the animal's sorting ability and highlight the importance of a balanced diet to optimize animal performance (Zanton and Heinrichs, 2016).

The better performance presented by animals fed $51 \%$ of RUP, with greater ADG, N retention, and feed efficiency values, reflects the increase in the flow of MP (Table 5), which likely increases the AA flow to the small intestine (Tomlinson et al., 1997). However, the importance of DMI and ME intake on animal performance must be highlighted, and although we have not found statistical differences for these variables at different RUP levels, they were numerically greater for animals fed $51 \%$ of RUP, which may have contributed to the better performance of these animals. 


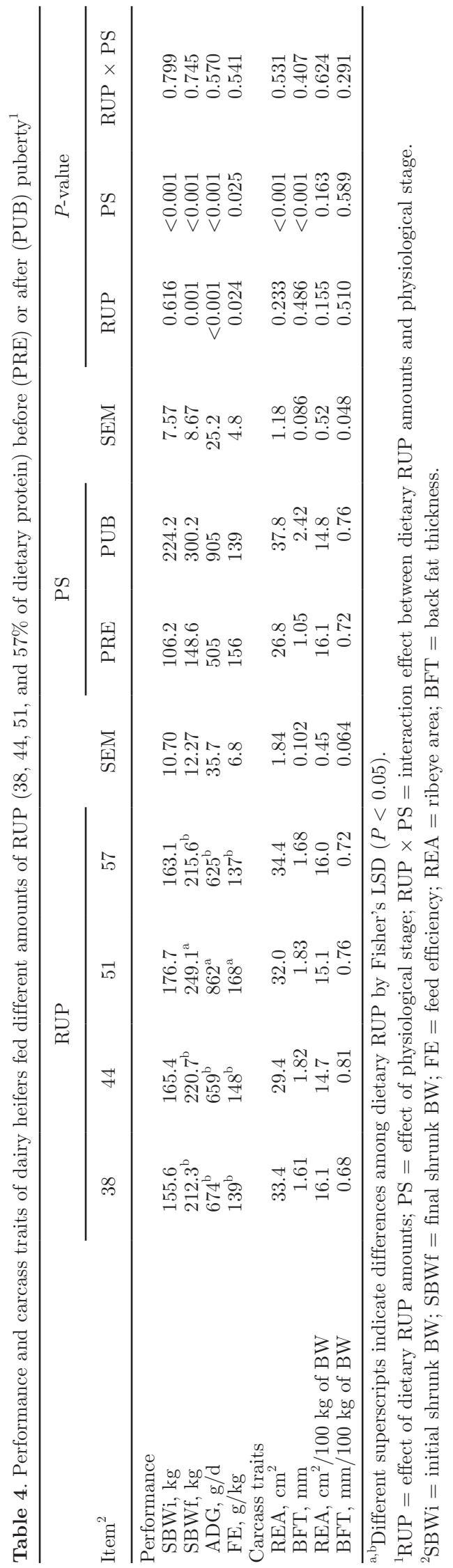

Journal of Dairy Science Vol. 101 No. 7, 2018

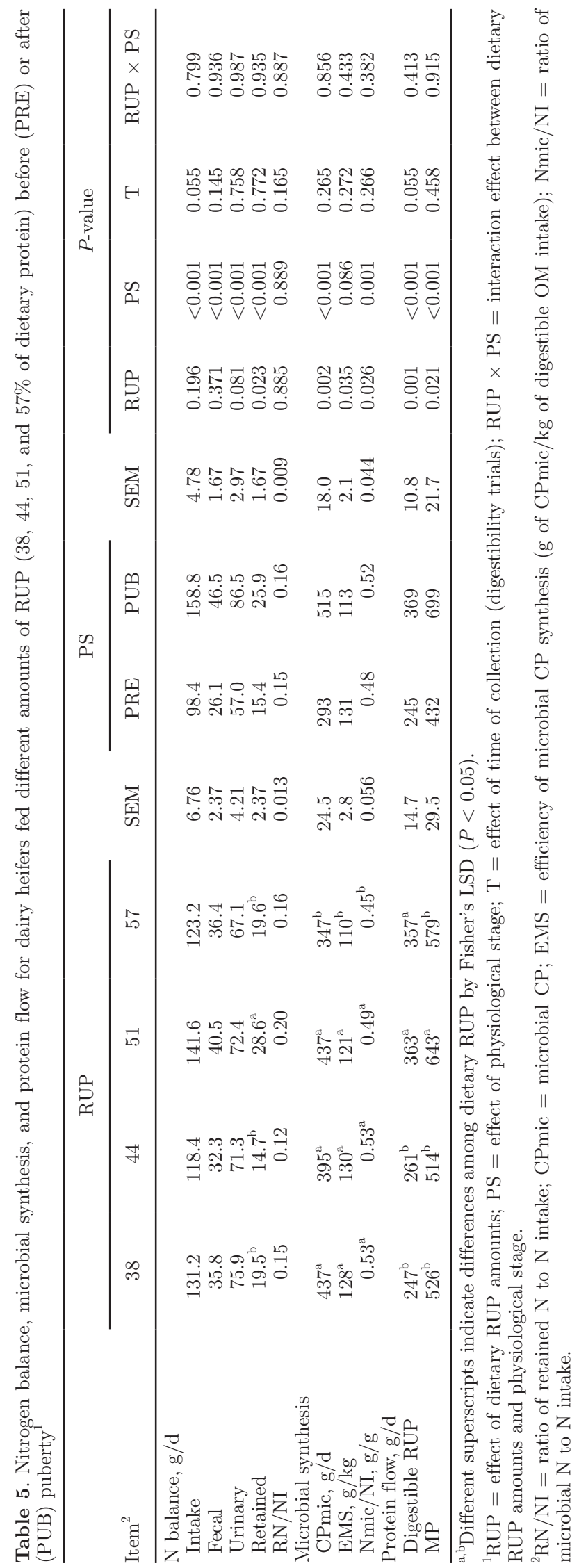


In addition, RUP supplementation is recognized as a glucogenic source and responsible for increasing serum insulin levels (Table 6; Wiley et al., 1991; Waterman et al., 2006). Thus, the best performance for animals fed $51 \%$ of RUP may also be linked to a greater insulin sensitivity caused by this level of RUP inclusion (Waterman et al., 2014).

In addition, increasing dietary RUP amounts was responsible for a tendency to decrease urinary N excretion (Table 5), as also observed by Batista et al. (2016) when they moved the site of supplementation from the rumen to the abomasum. This fact may be due to a greater equilibrium between ruminal protein degradation and microbial protein synthesis, resulting in lower ruminal ammonia production and, consequently, lower urinary N excretion (Archibeque et al., 2007; Hristov, 2013).

The lack of effects of dietary RUP amounts on carcass traits and mammary gland development must to be interpreted as a positive result because the level of $51 \%$ of RUP was able to improve performance indices without any negative effects on body composition (Table 4) or on mammary gland composition (Table 6; Capuco et al., 2004; Moallem et al., 2004).

The greater values of pixels per square meter in the mammary gland images exhibited by PRE heifers suggest that these animals had a greater deposition of fat at the mammary gland than PUB heifers (Table 6). This result is in line with other studies (Sejrsen et al., 1982; Purup et al., 2000; Meyer et al., 2006), which demonstrates that changes in mammary gland development are more pronounced in PRE heifers because these animals are in the allometric phase of mammary gland growth (Sinha and Tucker, 1969). Furthermore, it is widely affirmed that negative effects (fat deposition) on mammary gland development are more pronounced when the animals are submitted to nutritional planes that promote high performance rates (Whitlock et al., 2002; Piantoni et al., 2012). However, our results suggest that the proportion of fat at the mammary gland is greater for PRE than for PUB heifers, even when PRE heifers are under moderate ADG (Tables 4 and 6).

The greater fat proportion at the mammary gland is in opposition to the idea that animals with moderate growth rates have a greater proportion of protein in the body gain (Bartlett et al., 2006). However, this result appears to be linked to the lower levels of IGF-I in PRE heifers (Table 6), which can be a result of the lower ME intake (Mcal/kg of DM; Table 2) of these animals because the IGF-I concentration is directly affected by restrictions in feed intake (McGuire et al., 1992; Hornick et al., 2000). The IGF-I is an important factor for mammary gland development because of its effect on ductal growth (Purup et al., 2000; Berryhill et al., 
2016) and its positive relationship with body protein deposition (Anderson et al., 1988); therefore, lower IGF-I concentrations could negatively affect mammary gland development in PRE heifers.

\section{CONCLUSIONS}

The amount of $51 \%$ of RUP of the total dietary CP appears to be adequate in the diet of growing heifers because it optimized $\mathrm{N}$ retention and performance without negative effects on carcass and mammary gland growth. Additionally, there was no interaction effect between increasing amounts of RUP and PS on intake, performance, and mammary gland development. Prepubertal heifers presented a tendency to have a lower sorting ability for protein, lower total-tract digestibility and performance, and a higher amount of fat in their mammary gland compared with PUB heifers.

\section{ACKNOWLEDGMENTS}

We are grateful to the following Brazilian foundations for their help in this study: Coordenação de Aperfeiçoamento de Pessoal de Nível Superior (CAPES), Conselho Nacional de Desenvolvimento Científico e Tecnológico $(\mathrm{CNPq})$, and Fundação de Amparo à Pesquisa do Estado de Minas Gerais (FAPEMIG) Instituto de Ciência e Tecnologia de Ciência Animal (INCT-CA). We are also grateful to the Cargill/Nutron company (Campinas, Brazil) for supporting this study.

\section{REFERENCES}

Albino, R. L., S. E. F. Guimarães, K. M. Daniels, M. M. S. Fontes, A. F. Machado, G. B. dos Santos, and M. I. Marcondes. 2017. Technical note: Mammary gland ultrasonography to evaluate mammary parenchymal composition in prepubertal heifers. J. Dairy Sci. 100:1588-1591. https://doi.org/10.3168/jds.2016-11668.

Albino, R. L., M. I. Marcondes, R. M. Akers, E. Detmann, B. C. Carvalho, and T. E. Silva. 2015. Mammary gland development of dairy heifers fed diets containing increasing levels of metabolisable protein:metabolisable energy. J. Dairy Res. 82:113-120. https:// doi.org/10.1017/S0022029914000697.

Anderson, P. T., W. G. Bergen, R. A. Merkel, W. J. Enright, S. A. Zinn, K. R. Refsal, and D. R. Hawkins. 1988. The relationship between composition of gain and circulating hormones in growing beef bulls fed three dietary crude protein levels. J. Anim. Sci. 66:3059-3067. https://doi.org/10.2527/jas1988.66123059x.

AOAC International. 2005. Official Methods of Analysis. 18th ed. W. Horwitz, ed. AOAC International, Gaithersburg, MD.

Archibeque, S. L., H. C. Freetly, N. A. Cole, and C. L. Ferrell. 2007. The influence of oscillating dietary protein concentrations on finishing cattle. II. Nutrient retention and ammonia emissions. J. Anim. Sci. 85:1496-1503. https://doi.org/10.2527/jas.2006-208.

Bartlett, K. S., F. K. McKeith, M. J. VandeHaar, G. E. Dahl, and J. K. Drackley. 2006. Growth and body composition of dairy calves fed milk replacers containing different amounts of protein at two feeding rates. J. Anim. Sci. 84:1454-1467. https://doi.org/10 $.2527 / 2006.8461454 x$

Bascom, S. A., R. E. James, M. L. McGilliard, and M. Van Amburgh. 2007. Influence of dietary fat and protein on body composition of
Jersey bull calves. J. Dairy Sci. 90:5600-5609. https://doi.org/10 $.3168 /$ jds.2007-0004.

Batista, E. D., E. Detmann, D. I. Gomes, L. M. A. Rufino, M. F. Paulino, S. C. Valadares Filho, M. O. Franco, C. B. Sampaio, and W. L. S. Reis. 2017. Effect of protein supplementation in the rumen, abomasum, or both on intake, digestibility, and nitrogen utilisation in cattle fed high-quality tropical forage. Anim. Prod. Sci. 57:1993-2000. https://doi.org/10.1071/AN15736.

Batista, E. D., E. Detmann, E. C. Titgemeyer, S. C. Valadares Filho, R. F. D. Valadares, L. L. Prates, L. N. Rennó, and M. F. Paulino. 2016. Effects of varying ruminally undegradable protein supplementation on forage digestion, nitrogen metabolism, and urea kinetics in Nellore cattle fed low-quality tropical forage. J. Anim. Sci. 94:201-216. https://doi.org/10.2527/jas.2015-9493.

Berryhill, G. E., J. F. Trott, and R. C. Hovey. 2016. Mammary gland development-It's not just about estrogen. J. Dairy Sci. 99:875883. https://doi.org/10.3168/jds.2015-10105.

Bethard, G. L., R. E. James, and M. L. McGilliard. 1997. Effect of rumen-undegradable protein and energy on growth and feed efficiency of growing Holstein heifers. J. Dairy Sci. 80:2149-2155. https://doi.org/10.3168/jds.S0022-0302(97)76161-7.

Brown, E. G., M. J. Vandehaar, K. M. Daniels, J. S. Liesman, L. T. Chapin, D. H. Keisler, and M. S. W. Nielsen. 2005. Effect of increasing energy and protein intake on body growth and carcass composition of heifer calves. J. Dairy Sci. 88:585-594. https://doi .org/10.3168/jds.S0022-0302(05)72722-3.

Calsamiglia, S., and M. D. Stern. 1995. A three-step in vitro procedure for estimating intestinal digestion of protein in ruminants. J. Anim. Sci. 73:1459-1465. https://doi.org/10.2527/1995.7351459x.

Capuco, A. V., G. E. Dahl, D. L. Wood, U. Moallem, and R. E. Erdman. 2004. Effect of bovine somatotropin and rumen-undegradable protein on mammary growth of prepubertal dairy heifers and subsequent milk production. J. Dairy Sci. 87:3762-3769. https:// doi.org/10.3168/jds.S0022-0302(04)73514-6.

Chen, X. B., and M. J. Gomes. 1992. Estimation of Microbial Protein Supply to Sheep and Cattle Based on Urinary Excretion of Purine Derivatives-An Overview of the Technical Details. Rowett Research Institute, Bucksburnd Aberdeen, Scotland.

Chizzotti, M. L., S. C. Valadares Filho, R. F. D. Valadares, F. H. M. Chizzotti, and L. O. Tedeschi. 2008. Determination of creatinine excretion and evaluation of spot urine sampling in Holstein cattle. Livest. Sci. 113:218-225. https://doi.org/10.1016/j.livsci.2007.03 .013 .

Cooke, R. F., and J. D. Arthington. 2009. Plasma progesterone concentrations as puberty criteria for Brahman-crossbred heifers. Livest. Sci. 123:101-105. https://doi.org/10.1016/j.livsci.2008.10.009.

Daniels, K. M., A. V. Capuco, M. L. McGilliard, R. E. James, and R. M. Akers. 2009. Effects of milk replacer formulation on measures of mammary growth and composition in Holstein heifers. J. Dairy Sci. 92:5937-5950. https://doi.org/10.3168/jds.2008-1959.

Detmann, E., M. A. Souza, and S. C. Valadares Filho. 2012. Métodos para análises de alimentos. 1st ed. E. Detmann, M. A. Souza, and S. C. Valadares Filho, ed. Suprema, Visconde do Rio Branco, Minas Gerais, Brazil.

Fujihara, T., E. R. Ørskov, P. J. Reeds, and D. J. Kyle. 1987. The effect of protein infusion on urinary excretion of purine derivatives in ruminants nourished by intragastric nutrition. J. Agric. Sci. 109:7-12. https://doi.org/10.1017/S0021859600080916.

Geiger, A. J., C. L. M. Parsons, and R. M. Akers. 2016. Feeding a higher plane of nutrition and providing exogenous estrogen increases mammary gland development in Holstein heifer calves. J. Dairy Sci. 99:7642-7653. https://doi.org/10.3168/jds.2016-11283.

Hornick, J. L., C. Van Eenaeme, O. Gérard, I. Dufrasne, and L. Istasse. 2000. Mechanisms of reduced and compensatory growth. Domest. Anim. Endocrinol. 19:121-132. https://doi.org/10.1016/ S0739-7240(00)00072-2.

Hristov, A. N. 2013. Diet formulation as an effective tool for mitigating nitrogen excretion in dairy systems. Adv. Anim. Biosci. 4:15-18. https://doi.org/10.1017/S2040470013000265.

Jiao, H., T. Yan, D. A. Wills, A. F. Carson, and D. A. McDowell. 2014 Development of prediction models for quantification of total meth- 
ane emission from enteric fermentation of young Holstein cattle at various ages. Agric. Ecosyst. Environ. 183:160-166. https://doi .org/10.1016/j.agee.2013.11.004.

Leonardi, C., and L. E. Armentano. 2003. Effect of quantity, quality, and length of alfalfa hay on selective consumption by dairy cows. J. Dairy Sci. 86:557-564. https://doi.org/10.3168/jds.S0022 -0302(03)73634-0.

McGuire, M. A., J. L. Vicini, D. E. Bauman, and J. J. Veenhuizen. 1992. Insulin-like growth factors and binding proteins in ruminants and their nutritional regulation. J. Anim. Sci. 70:2901-2910. https://doi.org/10.2527/1992.7092901x.

Meyer, M. J., A. V. Capuco, D. A. Ross, L. M. Lintault, and M. E. Van Amburgh. 2006. Developmental and nutritional regulation of the prepubertal heifer mammary gland: I. Parenchyma and fat pad mass and composition. J. Dairy Sci. 89:4289-4297. https://doi .org/10.3168/jds.S0022-0302(06)72475-4.

Mezzomo, R., P. V. R. Paulino, E. Detmann, S. C. Valadares Filho, M. F. Paulino, J. P. I. S. Monnerat, M. S. Duarte, L. H. P. Silva, and L. S. Moura. 2011. Influence of condensed tannin on intake, digestibility, and efficiency of protein utilization in beef steers fed high concentrate diet. Livest. Sci. 141:1-11. https://doi.org/10.1016/j .livsci.2011.04.004.

Moallem, U., G. E. Dahl, E. K. Duffey, A. V. Capuco, D. L. Wood, K. R. McLeod, R. L. Baldwin, and R. A. Erdman. 2004. Bovine somatotropin and rumen-undegradable protein effects in prepubertal dairy heifers: Effects on body composition and organ and tissue weights. J. Dairy Sci. 87:3869-3880. https://doi.org/10.3168/jds .S0022-0302(04)73526-2.

Nishimura, M., T. Yoshida, S. El-Khodery, M. Miyoshi, H. Furuoka, J. Yasuda, and K. Miyahara. 2011. Ultrasound imaging of mammary glands in dairy heifers at different stages of growth. J. Vet. Med. Sci. 73:19-24. https://doi.org/10.1292/jvms.09-0503.

NRC. 2001. Nutrient Requirements of Dairy Cattle. 7th ed. National Academy Press, Washington, DC.

Paz, H. A., T. J. Klopfenstein, D. Hostetler, S. C. Fernando, E. Castillo-Lopez, and P. J. Kononoff. 2014. Ruminal degradation and intestinal digestibility of protein and amino acids in high-protein feedstuffs commonly used in dairy diets. J. Dairy Sci. 97:64856498. https://doi.org/10.3168/jds.2014-8108.

Piantoni, P., K. M. Daniels, R. E. Everts, S. L. Rodriguez-Zas, H. A. Lewin, W. L. Hurley, R. M. Akers, and J. J. Loor. 2012. Level of nutrient intake affects mammary gland gene expression profiles in preweaned Holstein heifers. J. Dairy Sci. 95:2550-2561. https://doi .org/10.3168/jds.2011-4539.

Prates, L. L., R. F. D. Valadares, S. C. Valadares Filho, E. Detmann, S. A. Santos, J. M. S. Braga, S. G. Pellizzoni, and K. S. Barbosa. 2012. Endogenous fraction and urinary recovery of purine derivatives in Nellore and Holstein heifers with abomasal purine infusion. Livest. Sci. 150:179-186. https://doi.org/10.1016/j.livsci .2012.08.018.

Provenza, F. D., and D. F. Balph. 1987. Diet learning by domestic ruminants: Theory, evidence and practical implications. Appl. Anim. Behav. Sci. 18:211-232. https://doi.org/10.1016/0168 -1591(87)90218-8.

Purup, S., M. Vestergaard, M. S. Weber, K. Plaut, R. M. Akers, and K. Sejrsen. 2000. Local regulation of pubertal mammary growth in heifers. J. Anim. Sci. 78:36-47. https://doi.org/10.2527/2000 .78suppl_336x.

Ribeiro, M. D., J. C. Pereira, R. A. M. Vieira, B. M. Pacheco, and F. D. P. Leonel. 2005. Consumo e desempenho de novilhas em pastagem recebendo suplementos com diferentes níveis de proteína nãodegradável no rúmen. Rev. Bras. Zootec. 34:2486-2495. https:// doi.org/10.1590/S1516-35982005000700037.

Rowson, A. R., K. M. Daniels, S. E. Ellis, and R. C. Hovey. 2012. Growth and development of the mammary glands of livestock: A veritable barnyard of opportunities. Semin. Cell Dev. Biol. 23:557566. https://doi.org/10.1016/j.semcdb.2012.03.018.
Santos, F. A. P., J. E. P. Santos, C. B. Theurer, and J. T. Huber. 1998. Effects of rumen-undegradable protein on dairy cow performance: A 12-year literature review. J. Dairy Sci. 81:3182-3213. https://doi .org/10.3168/jds.S0022-0302(98)75884-9.

SAS Institute Inc. 2008. SAS/STAT 9.2 User's Guide. SAS Institute Inc., Cary, NC.

Sejrsen, K., J. Foldager, M. T. Sorensen, R. M. Akers, and D. E. Bauman. 1986. Effect of exogenous bovine somatotropin on pubertal mammary development in heifers. J. Dairy Sci. 69:1528-1535. https://doi.org/10.3168/jds.S0022-0302(86)80569-0.

Sejrsen, K., J. T. Huber, H. A. Tucker, and R. M. Akers. 1982. Influence of nutrition on mammary development in pre- and postpubertal heifers. J. Dairy Sci. 65:793-800. https://doi.org/10.3168/ jds.S0022-0302(82)82268-6.

Sejrsen, K., and S. Purup. 1997. Influence of prepubertal feeding level on milk yield potential of dairy heifers: A review. J. Anim. Sci. 75:828-835. https://doi.org/10.2527/1997.753828x.

Sinha, Y. N., and H. A. Tucker. 1969. Mammary development and pituitary prolactin level of heifers from birth through puberty and during the estrous cycle. J. Dairy Sci. 52:507-512. https://doi.org/ 10.3168/jds.S0022-0302(69)86595-1.

Tomlinson, D. L., R. E. James, G. L. Bethard, and M. L. McGilliard. 1997. Influence of undegradability of protein in the diet on intake, daily gain, feed efficiency, and body composition of Holstein heifers. J. Dairy Sci. 80:943-948. https://doi.org/10.3168/jds.S0022 -0302(97)76018-1.

Valadares, R. F. D., G. A. Broderick, S. C. V. Filho, and M. K. Clayton. 1999. Effect of replacing alfalfa silage with high moisture corn on ruminal protein synthesis estimated from excretion of total purine derivatives. J. Dairy Sci. 82:2686-2696. https://doi.org/10 .3168/jds.S0022-0302(99)75525-6.

Valente, T. N. P., E. Detmann, A. C. Queiroz, S. C. Valadares Filho, D. I. Gomes, and J. F. Figueiras. 2011. Evaluation of ruminal degradation profiles of forages using bags made from different textiles. Rev. Bras. Zootec. 40:2565-2573. https://doi.org/10.1590/S1516 $-35982011001100039$

Waterman, R. C., J. E. Sawyer, K. K. Kane, D. E. Hawkins, and M. K. Petersen. 2014. Heifer body weight gain and reproductive achievement in response to protein and energy supplementation while grazing dormant range forage. Agric. Sci. 5:1296-1304. https://doi .org/10.4236/as.2014.513138.

Waterman, R. C., J. E. Sawyer, C. P. Mathis, D. E. Hawkins, G. B. Donart, and M. K. Petersen. 2006. Effects of supplements that contain increasing amounts of metabolizable protein with or without Ca-propionate salt on postpartum interval and nutrient partitioning in young beef cows. J. Anim. Sci. 84:433-446. https://doi .org/10.2527/2006.842433x.

Whitlock, B. K., M. J. VandeHaar, L. F. P. Silva, and H. A. Tucker 2002. Effect of dietary protein on prepubertal mammary development in rapidly growing dairy heifers. J. Dairy Sci. 85:1516-1525. https://doi.org/10.3168/jds.S0022-0302(02)74221-5.

Wiley, J. S., M. K. Petersen, R. P. Ansotegui, and R. A. Bellows. 1991. Production from first-calf beef heifers fed a maintenance or low level of prepartum nutrition and ruminally undegradable or degradable protein postpartum. J. Anim. Sci. 69:4279-4293. https:// doi.org/10.2527/1991.69114279x.

Zanton, G. I., M. T. Gabler, and A. J. Heinrichs. 2007. Manipulation of soluble and rumen-undegradable protein in diets fed to postpubertal dairy heifers. J. Dairy Sci. 90:978-986. https://doi.org/10 .3168/jds.S0022-0302(07)71582-5.

Zanton, G. I., and A. J. Heinrichs. 2016. Efficiency and rumen responses in younger and older Holstein heifers limit-fed diets of differing energy density. J. Dairy Sci. 99:2825-2836. https://doi .org/10.3168/jds.2015-10316. 